May 2012

\title{
Virulence markers of Helicobacter pylori in patients with diarrhoea-dominant irritable bowel syndrome.
}

Javed Yakoob

Aga Khan University

Zaigham Abbas

Aga Khan University

S. Naz

Aga Khan University

M. Islam

Aga Khan University

Waseem Jafri

Aga Khan University

Follow this and additional works at: https://ecommons.aku.edu/pakistan_fhs_mc_med_med Part of the Digestive System Diseases Commons

\section{Recommended Citation}

Yakoob, J., Abbas, Z., Naz, S., Islam, M., Jafri, W. (2012). Virulence markers of Helicobacter pylori in patients with diarrhoea-dominant irritable bowel syndrome.. British Journal of Biomedical Science, 69(1), 6-10.

Available at: https://ecommons.aku.edu/pakistan_fhs_mc_med_med/110 


\title{
Virulence markers of Helicobacter pylori in patients with diarrhoea-dominant irritable bowel syndrome
}

\author{
J. Yakoob, Z. Abbas, S. Naz, M. Islam \& W. Jafri
}

To cite this article: J. Yakoob, Z. Abbas, S. Naz, M. Islam \& W. Jafri (2012) Virulence markers of Helicobacter pylori in patients with diarrhoea-dominant irritable bowel syndrome, British Journal of Biomedical Science, 69:1, 6-10, DOI: 10.1080/09674845.2012.11669914

To link to this article: https://doi.org/10.1080/09674845.2012.11669914

曲 Published online: 20 Jan 2016.

Submit your article to this journal $\pi$

Џ Article views: 11

Citing articles: 4 View citing articles 5 


\section{Virulence markers of Helicobacter pylori in patients with diarrhoea-dominant irritable bowel syndrome}

\author{
J. YAKOOB, Z. ABBAS, S. NAZ, M. ISLAM and W. JAFRI \\ Department of Medicine, The Aga Khan University, Karachi, Pakistan
}

Accepted: 15 December 2011

\section{Introduction}

Helicobacter pylori is a highly prevalent Gram-negative microaerophilic bacterium. It causes chronic gastric infection leading to gastritis, peptic ulcer and eventually gastric cancer $^{1-3} H$. pylori infection is associated with remodelling of gastric mucosal nerves ${ }^{4}$ and stimulation of mast cells. ${ }^{5,6}$ In animal models, $H$. pylori infection increases the neural responsiveness of smooth muscle. ${ }^{7}$

Virulence markers of $H$. pylori cytotoxin associated gene $(\operatorname{cag} A)$ and vacuolating cytotoxin gene (vacA) are associated with different gastroduodenal diseases. ${ }^{8,9}$ Most $H$. pylori strains secrete a VacA cytotoxin that causes structural and functional alterations in epithelial cells and play an important role in the pathogenesis of $H$. pylori-associated gastroduodenal diseases.

Mutation of a hydrophobic region near the VacA amino terminus produces a mutant toxin that fails to induce cell vacuolation with defective functional activity. ${ }^{10}$ VacA forms anion-selective channels in artificial planar lipid bilayers that increase the anion permeability of the HeLa cell plasma membrane and determines membrane depolarisation. ${ }^{11}$

When added to cultured cells, VacA induces vacuolation, an effect potentiated by pre-exposure of the toxin to low $\mathrm{pH}$. The anion-selective, voltage-dependent pores formed in artificial membranes are potentiated by acidic conditions. ${ }^{12}$ Pore formation is required both for cell vacuolation and increase of transepithelial conductivity. ${ }^{12}$

Purified $\mathrm{pH}$-activated VacA, when added to Caco- 2 cell monolayers, demonstrates enterotoxic effect. ${ }^{13}$ This is timeand dose-dependent and is saturable. ${ }^{13}$ Although VacA is produced by $H$. pylori in the stomach, it may exert an effect on more distal regions of the intestine. In gastric and small bowel epithelia, VacA is known to produce acidic ballooning of the endoplasmic reticulum and permeabilisation of the cell membrane, independent of the cytopathic effects. ${ }^{14}$

In children with diarrhoea, a cytotoxin-inducing vacuolation in HEp-2 cells was detected in 19 out of 618 stool specimens, and these resembled those induced by the vac $A$ of H. pylori. $^{15}$

The prevalence of H. pylori seropositivity in the authors'

Correspondence to: Dr. Javed Yakoob

Department of Medicine, Aga Khan University Hospital

Stadium Road, Karachi-74800, Pakistan

Email:yakoobjaved@hotmail.com

\section{ABSTRACT}

Recent studies suggest that irritable bowel syndrome (IBS) is associated with low-grade inflammation. This study aims to determine the distribution of Helicobacter pylori cytotoxin-associated gene $\mathrm{A}(\operatorname{cag} A)$ and vacuolating cytotoxin A (vacA) alleles (e.g., s1 and s2) in patients with diarrhoea-dominant IBS (IBS-D) as the latter causes vacuolation in colonic epithelial cells in vitro. One hundred and seventy patients meeting Rome III criteria for IBS-D (mean age: $40 \pm 15$ years) were enrolled. Gastric biopsy was assessed histologically and DNA extraction was performed by polymerase chain reaction (PCR) for $H$. pylori genus $16 \mathrm{~S}$ ribosomal DNA (16S rDNA), cagA and vacA allele $s 1$ and $s 2$. There was no age- or gender-related difference in $H$. pylori positivity in IBS-D compared to the control group. H. pylori was positive in $116(68 \%)$ with IBS-D compared to $88(55 \%)$ in the control group ( $P=0.01)$. cag $A$ was positive in $73(63 \%)$ with IBS-D compared to $42(48 \%)$ in the control group $(P=0.03)$. vacA s1 was positive in $61(53 \%)$ with IBS-D compared to $32(36 \%)$ in the control group $(P=0.02)$. cagA s1 was positive in $39(34 \%)$ with IBS-D compared to $13(15 \%)$ in the control group $(P=0.002)$.

KEY WORDS: cagA.

Helicobacter pylori.

Irritable bowel syndrome.

vacA alleles.

local population in children aged $11-15$ years is $53.5 \% .^{16}$ In another study where $H$. pylori infection was established by rapid urease test and histopathology, cagA-negative $H$. pylori infection was present in the majority of non-ulcer dyspepsia patients; however, $\operatorname{cag} A$ was associated with peptic ulcer and gastric carcinoma. ${ }^{17}$ vacA alleles s1am1 and s1bm1 are associated with $H$. pylori-associated disease and inflammation. ${ }^{17}$

The aim of the present study is to determine the distribution of the $H$. pylori virulence markers cagA and vacA in irritable bowel syndrome with diarrhoea (IBS-D) according to the Rome III criteria, compared to the distribution in patients with chronic diarrhoea.

\section{Materials and methods}

A total of 330 patients were enrolled in the study, comprising $170(52 \%)$ with IBS-D and $160(48 \%)$ with chronic diarrhoea. Mean age of the IBS-D group was $41 \pm 15$ years (range: $16-83$; males: 116, females: 54). Mean age of the 160 patients with chronic diarrhoea used as controls was $42 \pm 14$ years (range 15-75; males: 106, females: 54). Patients in the control group had abdominal pain or discomfort associated with 
intermittent diarrhoea that did not fulfill the Rome III criteria for IBS-D.

Patients meeting the Rome III criteria for IBS-D had symptoms for at least three months, with onset at least six months previously. ${ }^{18}$ These patients underwent thorough history, physical examination, complete blood count, serum creatinine, electrolytes, stool microscopy, oesophagogastroduodenoscopy (EGD) and colonoscopy. On EGD, gastric and duodenal biopsies were taken for $H$. pylori infection, coeliac disease and giardiasis. On colonoscopy, rectal biopsy was taken for the diagnosis of inflammatory bowel disease, microscopic colitis and infective colitis. They also had serology for tissue transglutaminase (TTG) IgA and IgG antibodies for coeliac disease.

Gastric biopsy specimens were used for histopathology for the diagnosis of $H$. pylori and DNA extraction for the polymerase chain reaction (PCR) to amplify $H$. pylori genes for ribosomal DNA (rDNA), cagA and vacA alleles s1 and s2.

Gastritis was graded on a four-point scale of none (grade 0 ), mild (grade 1), moderate (grade 2), and severe (grade 3) according to the Sydney guidelines. ${ }^{19}$ The presence of H. pylori was assessed on haematoxylin and eosin (H\&E)stained sections. Diagnosis of $H$. pylori infection was established when PCR for 16S rDNA or a specific PCR for H. pylori was positive.

Exclusion criteria included previous history of peptic ulcer disease, history of treatment for $H$. pylori, concurrent or recent antibiotic use (e.g., metronidazole, clarithromycin, amoxicillin, tetracycline, doxycycline and other cephalosporins), histamine-2 receptor blocker or proton pump inhibitor therapy, and concurrent infection with Blastocystis hominis or Giardia lamblia.

The study was approved by the institutional ethics review committee.

\section{Faecal smear microscopy}

Briefly, approximately $2 \mathrm{mg}$ faeces was emulsified on a glass slide in one drop of physiological saline and covered with a cover slip. A similar preparation was made on another slide using Lugol's iodine. These preparations were examined under low power $(x 10)$ and high power $(x 40)$ objective lenses.

\section{Extraction of genomic DNA}

The extraction of DNA was performed as described previously. ${ }^{20}$ Briefly, gastric tissue was homogenised in $500 \mu \mathrm{L}$ sterile water and centrifuged at 12,000 x $\mathrm{g}$ for $3 \mathrm{~min}$. Then, $500 \mu \mathrm{L}$ lysis buffer $(100 \mathrm{mmol} / \mathrm{L} \mathrm{NaCl}, 10 \mathrm{mmol} / \mathrm{L}$ Tris- $\mathrm{HCl}$ [pH 8.0], $25 \mathrm{mmol} / \mathrm{L}$ EDTA, $0.5 \%$ sodium dodecyl sulphate) and $10 \mu \mathrm{L}$ proteinase $\mathrm{K}(10 \mathrm{mg} / \mathrm{mL})$ were added. Incubation was carried out at $50^{\circ} \mathrm{C}$ for $20 \mathrm{~h}$, followed by phenol-chloroform extraction and ethanol precipitation. The resulting pellet was allowed to dissolve in $40 \mu \mathrm{L}$ TE buffer $(10 \mathrm{mmol} / \mathrm{L}$ Tris- $\mathrm{HCl}$ [pH 7.4], $0.1 \mathrm{mmol} / \mathrm{L}$ EDTA [pH 8.0]) for $20 \mathrm{~h}$ at $37^{\circ} \mathrm{C}$. Samples were stored at $-20^{\circ} \mathrm{C}$ prior to PCR amplification. The DNA content and purity were determined by measuring the absorbance at $260 \mathrm{~nm}$ and $280 \mathrm{~nm}$, respectively, using a spectrophotometer (Beckman DU-600, USA).

\section{PCR amplification}

The PCR reaction was performed using extracted DNA as the template. Samples that were positive for Helicobacter genus $16 \mathrm{~S}$ rDNA were subsequently analysed with different primers to detect the $\operatorname{cag} A, \operatorname{cag} A$ empty site and vacA alleles (e.g., s1 and s2) (Table 1) which encode potential virulence factors in $H$. pylori. ${ }^{21,22}$ If $\operatorname{cag} A$ was negative, PCR was performed to confirm the presence of cag $A$ empty site in cagA-negative strains, and to eliminate cases of amplification failure. Primers used were those described previously. ${ }^{23,24}$

Amplification was carried out in a total volume of $50 \mathrm{~mL}$ containing $2 \mathrm{~mL} 2 \mathrm{mmol}$ dNTPs, $1 \mathrm{~mL} 50$ pmol each forward and reverse primer ${ }^{25,26}$ (synthesised by MWG automatic synthesiser), 1 unit Thermus aquaticus (Taq) DNA polymerase (Promega), $5 \mu \mathrm{L} \mathrm{10x} \mathrm{PCR} \mathrm{reaction} \mathrm{buffer,} 3 \mathrm{mmol} / \mathrm{L} \mathrm{MgCl}_{2}$ and $2 \mathrm{~mL}$ DNA template containing $0.5 \mathrm{ng}$ extracted DNA. Total volume was increased to $50 \mu \mathrm{L}$ by the addition of double-distilled water. The reaction was carried out in a Perkin Elmer 9700 thermal cycler, and the amplification cycles for the various $H$. pylori genes are shown in Table 1.

Table 1. Oligonucleotide primers used in typing $H$. pylori genes.

\begin{tabular}{|c|c|c|c|c|}
\hline Region amplified & $\begin{array}{c}\text { Primer } \\
\text { designation }\end{array}$ & Primer sequences $\left(5^{\prime} \rightarrow 3^{\prime}\right)$ & $\begin{array}{l}\text { PCR } \\
\text { product } \\
\text { (bp) }\end{array}$ & PCR cycles \\
\hline $16 \mathrm{~S}$ rRNA ${ }^{21}$ & $\begin{array}{l}\mathrm{C} 97 \\
\text { C } 98\end{array}$ & $\begin{array}{l}\text { GCT ATG ACG GGT ATC C } \\
\text { GAT TाT ACC CCT ACA CCA }\end{array}$ & 400 & $\begin{array}{l}94^{\circ} \mathrm{C} \text { for } 5 \mathrm{~min}, 94^{\circ} \mathrm{C} \text { for } 1 \mathrm{~min} \text {, } \\
55^{\circ} \mathrm{C} \text { for } 1 \mathrm{~min}, 72^{\circ} \mathrm{C} \text { for } 90 \mathrm{sec} \\
\text { (35 cycles), } 72^{\circ} \mathrm{C} \text { for } 7 \mathrm{~min}\end{array}$ \\
\hline vacA alleles ${ }^{22}$ & $\begin{array}{l}\mathrm{S} 1 \\
\mathrm{~S} 2\end{array}$ & $\begin{array}{l}\text { ATGGAAATACAACAAACACAC } \\
\text { CTGCTTGAATGCGCCAAAC }\end{array}$ & $\begin{array}{l}259^{19} \\
286^{19}\end{array}$ & $\begin{array}{l}\text { One cycle of } 95^{\circ} \mathrm{C} \text { for } 5 \mathrm{~min} \text {, } \\
35 \text { cycles of } 95^{\circ} \mathrm{C} \text { for } 1 \mathrm{~min} \text {, } \\
52^{\circ} \mathrm{C} \text { for } 1 \mathrm{~min}, 72^{\circ} \mathrm{C} \text { for } 1 \mathrm{~min} \text {, } \\
\text { and one cycle of } 72^{\circ} \mathrm{C} \text { for } 5 \mathrm{~min}\end{array}$ \\
\hline $\operatorname{cag} A^{23}$ & $\begin{array}{l}\text { D008 } \\
\text { R008 }\end{array}$ & $\begin{array}{c}\text { GGTCAAAATGCGGTCATGG } \\
\text { TTAGAATAATCAACAAACATCACGCCAT }\end{array}$ & $297^{19}$ & $\begin{array}{l}\text { One cycle of } 94^{\circ} \mathrm{C} \text { for } 5 \mathrm{~min} \text {, } \\
35 \text { cycles of } 94^{\circ} \mathrm{C} \text { for } 1 \mathrm{~min}, \\
55^{\circ} \mathrm{C} \text { for } 1 \mathrm{~min}, 72^{\circ} \mathrm{C} \text { for } 1 \mathrm{~min} \text {, } \\
\text { and one cycle of } 72^{\circ} \mathrm{C} \text { for } 5 \mathrm{~min}\end{array}$ \\
\hline Empty site ${ }^{24}$ & ES-F & $\begin{array}{l}\text { ACATTITGGCTAAATAAACGCTG } \\
\text { TCATGCGAGCGGCGATGTG }\end{array}$ & 360 & $\begin{array}{l}\text { One cycle of } 94^{\circ} \mathrm{C} \text { for } 5 \mathrm{~min} \text {, } \\
40 \text { cycles of } 94^{\circ} \mathrm{C} \text { for } 1 \mathrm{~min}, \\
55^{\circ} \mathrm{C} \text { for } 1 \mathrm{~min}, 72^{\circ} \mathrm{C} \text { for } 1 \mathrm{~min} \text {, } \\
\text { and one cycle of } 72^{\circ} \mathrm{C} \text { for } 5 \mathrm{~min}\end{array}$ \\
\hline
\end{tabular}


Positive and negative control reactions were performed with each batch of amplifications. DNA from $H$. pylori strains ATCC 43504 (vacAs1am1, cagA-positive), ATCC 51932 (vacA s2m2, cagA-negative) and ATCC 43526 (vacA s1bm1, $\operatorname{cag} A$-positive) was used to define the accuracy of the $c a g A$ and vacA alleles. After PCR, the amplified products were electrophoresed in 2\% agarose gels containing $0.5 \%$ Tris/acetate/ethylenediaminetetraacetic acid, stained with ethidium bromide, and visualised under an ultraviolet (UV) light source.

\section{Sample size}

Using NCSS (PASS) software for the sample size calculation, a group of 330 subjects was required to achieve $80 \%$ power to detect a difference of $15 \%$ that prevalence of $H$. pylori in IBS patient would be $69 \%$ when compared to the non-IBS group $^{16,25}$ at a $5 \%$ level of significance.

\section{Statistical analysis}

Results were expressed as mean+standard deviation (SD) for continuous variables (e.g., age) and number (percentage) for categorical data (e.g., gender, stool culture, diarrhoea). Univariate analysis was performed using the independent sample $t$-test, Pearson $\chi^{2}$ test and Fisher Exact test where appropriate. $P<0.05$ was considered statistically significant. All $P$ values were two sided. Statistical interpretation of data was performed using SPSS version 16.0.

\section{Results}

On EGD, H. pylori gastritis was present in $162(49 \%)$ patients and non-specific gastritis was present in $168(51 \%)$. At colonoscopy, $138(42 \%)$ had non-specific inflammation while $192(58 \%)$ were reported as normal (Table 2). On histopathology, gastric biopsy revealed chronic active gastritis in $90(53 \%)$ and chronic gastritis in $80(47 \%)$ patients with IBS-D compared to $63(39 \%)$ and $97(61 \%)$, respectively, in patients with chronic diarrhoea $(P=0.02)$. Colonic biopsies revealed non-specific inflammation in $90(53 \%)$ and normal colonic mucosa in $80(47 \%)$ in patients with IBS-D compared to $102(64 \%)$ and $58(36 \%)$, respectively, in patients with chronic diarrhoea $(P=0.05)$ (Table 2$)$.

\section{Prevalence of infection}

H. pylori was positive in $116(68 \%)$ with IBS-D compared to $88(55 \%)$ in the control group $(P=0.01)$. It was associated with $H$. pylori-positive gastritis in $91(54 \%)$ patients with IBS-D compared to $71(44 \%)$ in the control group $(P=0.09)$ (Table 2).

\section{Distribution of virulence markers}

cagA was positive in 115 (56\%), cagA empty site in $89(44 \%)$, vacAs1 in $93(46 \%)$, vacAs2 in $124(61 \%)$, cagAs1 in $53(26 \%)$ and cagAs2 in 68 (33\%) (Figs. 2 and 3). cagA was positive in $73(63 \%)$ patients with IBS-D compared to $42(48 \%)$ in the control group $(P=0.03)$ (Table 2$). H$. pylori infection with cagA empty site was positive in $43(37 \%)$ in patients with IBS-D and $46(52 \%)$ in the control group $(P=0.03)$. vacAs1 was positive in $61(53 \%)$ patients with IBS-D compared to $32(36 \%)$ in the control group $(P=0.02)$ (Table 2). cagAs1 was positive in $39(34 \%)$ patients with IBS-D compared to $13(15 \%)$ in the control group $(P=0.002)$ (Table 2$)$.
Table 2. Details of patients enrolled in the study.

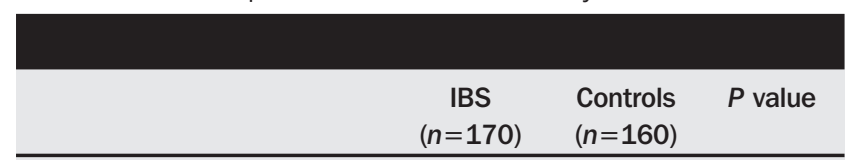

\begin{tabular}{lccc}
\hline Age & & & \\
Mean \pm SD & $40 \pm 15$ & $42 \pm 14$ & \\
Range & $16-83$ & $15-75$ & \\
\hline Gender & & & \\
\hline Male & $116(69)$ & $106(66)$ & \\
\hline Female & $54(31)$ & $54(34)$ & \\
\hline EGD & & & \\
\hline H. pylori-positive gastritis & $91(54)$ & $71(44)$ & 0.09 \\
\hline H. pylori-negative gastritis & $79(46)$ & $89(56)$ & \\
\hline Colonoscopy & & & \\
\hline Normal & $80(47)$ & $58(36)$ & 0.05 \\
\hline Non-specific & $90(53)$ & $102(64)$ & \\
\hline
\end{tabular}

\begin{tabular}{|c|c|c|c|}
\hline \multicolumn{4}{|c|}{ PCR for Helicobacter pylori } \\
\hline \multicolumn{4}{|l|}{$16 \mathrm{~S}$ rDNA } \\
\hline Positive & $116(68)$ & $88(55)$ & 0.01 \\
\hline Negative & $54(43)$ & $72(45)$ & \\
\hline \multicolumn{4}{|l|}{ cagA } \\
\hline Positive & $73(63)$ & $42(48)$ & 0.03 \\
\hline Negative & $43(37)$ & $46(52)$ & \\
\hline \multicolumn{4}{|c|}{ cagA-empty site } \\
\hline Positive & $43(37)$ & $46(52)$ & 0.03 \\
\hline Negative & $73(63)$ & $42(48)$ & \\
\hline \multicolumn{4}{|l|}{ vacAs1 } \\
\hline Positive & $61(53)$ & $32(36)$ & 0.02 \\
\hline Negative & $55(47)$ & $56(64)$ & \\
\hline \multicolumn{4}{|l|}{ vacAs2 } \\
\hline Positive & $67(58)$ & $57(65)$ & 0.31 \\
\hline Negative & $49(42)$ & $31(35)$ & \\
\hline \multicolumn{4}{|l|}{ cagAs1 } \\
\hline Positive & $39(34)$ & $13(15)$ & 0.002 \\
\hline Negative & $77(66)$ & $75(85)$ & \\
\hline \multicolumn{4}{|l|}{ cagAs2 } \\
\hline Positive & 38(33) & $30(34)$ & 0.84 \\
\hline Negative & $78(67)$ & $58(66)$ & \\
\hline
\end{tabular}

Univariate analysis was performed using the independent sample t-test; Pearson $\chi^{2}$ test and Fisher Exact test were also used where appropriate. $P<0.05$ was considered statistically significant. Percentage shown in parentheses.

\section{Comparison of infection in different groups}

No age- or gender-related differences in $H$. pylori positivity were seen, nor differences in $H$. pylori-associated gastritis in the two groups (Tables 2 and 3 ). cagA was positive in $73(63 \%)$ patients with IBS-D compared to $42(48 \%)$ in the control group $(P=0.03)$, while vacAs1 was positive in $61(53 \%)$ with IBS-D compared to $32(36 \%)$ in the control group $(P=0.02)$ (Table 3$)$. cagAs1 was positive in $39(34 \%)$ patients with IBS-D compared to $14(16 \%)$ in the control group $(P=0.004)$ (Table 3$)$. 


\section{Discussion}

The implications of the study reported here are that $H$. pylori infection is associated with $H$. pylori strains that are cagAs1-positive, compared to a previously reported increased incidence of $\operatorname{cag} A$-negative $H$. pylori strains in patients with non-ulcer dyspepsia. ${ }^{17}$ It shows variation in the distribution of $H$. pylori virulence markers in IBS-D compared to non-ulcer dyspepsia.

There is evidence to suggest that $H$. pylori vacuolating toxin has a role in causing diarrhoea as it produces vacuolation in colonic epithelial cells. However, the present study did not demonstrate this effect, and was only able to show an increase in distribution of $H$. pylori virulence markers in IBS-D patients.

It is known that that co-infection with parasitic organisms tends to modulate the immune response, ${ }^{27}$ however, patients in the present study did not show evidence of infestation (e.g., Blastocystis hominis) on stool examination.

Irritable bowel syndrome is a heterogeneous disorder and not all patients with IBS give a history of gastroenteritis, pelvic surgery and psychological trauma. ${ }^{26}$ It is possible that $H$. pylori infection serves to sensitise the bowel and leads to the appearance of IBS symptoms. ${ }^{28}$ The VacA cytotoxin secreted by $H$. pylori strains may contribute to diarrhoea in IBS-D following structural and functional alterations to intestinal epithelial cells that increase their permeability. ${ }^{11}$

In conclusion, the present study showed that $H$. pylori infection is common in patients with IBS-D, and is associated with virulent strains that are predominantly cagAs1-positive. However, further studies are required to illustrate the effect of $H$. pylori virulence markers in patients with IBS.

The authors are grateful to the staff of the Juma Research Laboratory for their help during completion of this work.

\section{References}

1 Monack DM, Mueller A, Falkow S. Persistent bacterial infections: the interface of the pathogen and the host immune system. Nat Rev Microbiol 2004; 2 (9): 747-65.

2 Tsuji S, Kawano S. Peptic ulcer recurrence and Helicobacter pylori: evidence from Japan. J Gastroenterol 2003; 38 (4): 410-1.

3 Blaser MJ, Perez-Perez GI, Kleanthous $\mathrm{H}$ et al. Infection with Helicobacter pylori strains possessing $c a g A$ is associated with an increased risk of developing adenocarcinoma of the stomach. Cancer Res 1995; 55 (10): 2111-5.

4 Stead RH, Hewlett BR, Lhotak S, Colley ECC, Frendo M, Dixon MT. Do gastric mucosal nerves remodel in $\mathrm{H}$. pylori gastritis? In: Hunt RH, Tytgat GNJ eds. Helicobacter pylori: basic mechanism to clinical cure. Dordrecht: Kluwer Academic Publishers, 1994: 281-91.

5 Mayer EA, Gebhart GF. Basic and clinical aspects of visceral hyperalgesia. Gastroenterology 1994; 107 (1): 271-93.

6 Nakajima S, Nakajima S, Hattori T, Krishnan B, Ota H, El-Zimaity HM. Distribution of smooth muscle bundles in gastric mucosa with or without Helicobacter pylori infection and their relationship with mast cells. Gastroenterology 1998; 114 (Suppl 1): A239.

7 Shaffer SE, Felis MR. Decreased cholinergic and excitatory
Table 3. Comparison of Helicobacter positivity.

\begin{tabular}{|c|c|c|c|}
\hline & $\begin{array}{c}\text { IBS } \\
(n=116) \\
\end{array}$ & $\begin{array}{c}\text { Controls } \\
(n=88)\end{array}$ & $P$ value \\
\hline \multicolumn{4}{|l|}{ Age (years) } \\
\hline$\leq 42$ & $68(59)$ & $50(57)$ & 0.80 \\
\hline$\geq 43$ & $48(41)$ & $38(43)$ & \\
\hline \multicolumn{4}{|l|}{ Gender } \\
\hline Male & $79(68)$ & $50(63)$ & 0.40 \\
\hline Female & $37(32)$ & 33(37) & \\
\hline \multicolumn{4}{|l|}{ EGD } \\
\hline H. pylori-positive gastritis & $27(23)$ & $18(21)$ & 0.63 \\
\hline H. pylori-negative gastritis & $89(77)$ & $70(79)$ & \\
\hline \multicolumn{4}{|l|}{ Colonoscopy } \\
\hline Normal & $51(44)$ & 28(32) & 0.08 \\
\hline Non-specific & $65(56)$ & $60(68)$ & \\
\hline \multicolumn{4}{|l|}{ PCR for Helicobacter pylori } \\
\hline \multicolumn{4}{|l|}{$16 \mathrm{~S}$ rDNA } \\
\hline Positive & 116(68) & $88(55)$ & 0.01 \\
\hline Negative & $54(43)$ & $72(45)$ & \\
\hline \multicolumn{4}{|l|}{$\operatorname{cag} A$} \\
\hline Positive & $73(63)$ & $42(48)$ & 0.03 \\
\hline Negative & $43(37)$ & $46(52)$ & \\
\hline \multicolumn{4}{|l|}{ cagA-empty site } \\
\hline Positive & $43(37)$ & $46(52)$ & 0.03 \\
\hline Negative & $76(63)$ & 42(48) & \\
\hline \multicolumn{4}{|l|}{ vacAs1 } \\
\hline Positive & $61(53)$ & $32(36)$ & 0.02 \\
\hline Negative & $55(47)$ & $56(64)$ & \\
\hline \multicolumn{4}{|l|}{ vacAs2 } \\
\hline Positive & $67(58)$ & $57(65)$ & 0.31 \\
\hline Negative & $49(42)$ & $31(35)$ & \\
\hline \multicolumn{4}{|l|}{ cagAs1 } \\
\hline Positive & $39(34)$ & 14(16) & 0.004 \\
\hline Negative & $77(66)$ & $74(84)$ & \\
\hline \multicolumn{4}{|l|}{ cagAs2 } \\
\hline Positive & $38(33)$ & $30(34)$ & 0.84 \\
\hline Negative & $78(67)$ & $58(66)$ & \\
\hline
\end{tabular}

Univariate analysis was performed using the independent sample $t$-test; Pearson $\chi^{2}$ test and Fisher Exact test were also used where appropriate. $P<0.05$ was considered statistically significant. Percentage shown in parentheses.

neural responsiveness of smooth muscle in a model of Helicobacter gastritis. Gastroenterology 1996; 110 (Suppl 1): A756.

8 Censini S, Lange C, Xiang Z et al. cag, a pathogenecity island of $H$. pylori encodes type I-specific and disease-associated virulence factors. Proc Natl Acad Sci USA 1996; 93 (25): 14648-53.

9 Atherton JC, Cao P, Peek RM, Tummuru MKR, Blaser MJ, Cover TL. Mosaicism in vacuolating cytotoxin alleles of $H$. pylori. Association of specific vacA types with cytotoxin production and peptic ulceration. J Biol Chem 1995; 270 (30): 17771-7. 
10 Vinion-Dubiel AD, McClain MS, Czajkowsky DM et al. A dominant negative mutant of Helicobacter pylori vacuolating toxin (VacA) inhibits VacA-induced cell vacuolation. J Biol Chem 1999; 274 (53): 37736-42.

11 Szabò I, Brutsche S, Tombola F et al. Formation of anion-selective channels in the cell plasma membrane by the toxin VacA of Helicobacter pylori is required for its biological activity. EMBO J 1999; 18 (20): 5517-27.

12 Tombola F, Carlesso C, Szabò I et al. Helicobacter pylori vacuolating toxin forms anion-selective channels in planar lipid bilayers: possible implications for the mechanism of cellular vacuolation. Biophys J 1999; 76 (3): 1401-9.

13 Guarino A, Bisceglia M, Canani RB et al. Enterotoxic effect of the vacuolating toxin produced by Helicobacter pylori in Caco-2 cells. J Infect Dis 1998; 178 (5): 1373-8.

14 Pelicic V, Reyrat JM, Sartori L et al. Helicobacter pylori VacA cytotoxin associated with the bacteria increases epithelial permeability independently of its vacuolating activity. Microbiology 1999; 145 (Pt 8): 2043-50.

15 Luzzi I, Covacci A, Censini S et al. Detection of a vacuolating cytotoxin in stools from children with diarrhea. Clin Infect Dis 1996; 23 (1): 101-6.

16 Jafri W, Yakoob J, Abid S, Siddiqui S, Awan S, Nizami SQ. Helicobacter pylori infection in children: population-based agespecific prevalence and risk factors in a developing country. Acta Paediatr 2010; 99 (2): 279-82.

17 Yakoob J, Abid S, Abbas Z et al. Distribution of Helicobacter pylori virulence markers in patients with gastroduodenal diseases in Pakistan. BMC Gastroenterol 2009; 9: 87.

18 Longstreth GF, Thompson WG, Chey WD, Houghton LA, Mearin F, Spiller RC. Functional bowel disorders. Gastroenterology 2006; 130 (5): 1480-91.
19 Price AB. The Sydney System: histological division. J Gastroenterol Hepatol 1991; 6 (3): 209-22.

20 van Zwet AA, Thijs C, Kooistra-Smid AM, Schirm J, Snijder JA. Sensitivity of culture compared with that of polymerase chain reaction for detection of Helicobacter pylori from antral biopsy samples. J Clin Microbiol 1993; 31 (7): 1918-20.

21 Fox JG, Dewhirst FE, Shen Z et al. Hepatic Helicobacter species identified in bile and gallbladder tissue from Chileans with chronic cholecystitis. Gastroenterology 1998; 114 (4): 755-63.

22 Covacci A, Rappuoli R. PCR amplification of gene sequences from Helicobacter pylori strains. In: Lee A, Megraud F eds. Helicobacter pylori: techniques for clinical diagnosis and basic research. Philadelphia: WB Saunders, 1995: 94-109.

23 Akopyants NS, Clifton SW, Kersulyte D et al. Analyses of the cag pathogenicity island of Helicobacter pylori. Mol Microbiol 1998; 28 (1): 37-53.

24 Slater E, Owen RJ, Williams M, Pounder RE. Conservation of the cag pathogenicity island of Helicobacter pylori: associations with vacuolating cytotoxin allele and IS605 diversity. Gastroenterology 1999; 117 (6): 1308-15.

25 Hassan SR, Abbas Z. Presence of Helicobacter pylori in dyspeptic patients with endoscopically normal stomach. Pak J Med Sci Q 2007; 23: 335-9.

26 Gwee KA, Leong YL, Graham C et al. The role of psychological and biological factors in postinfective gut dysfunction. Gut 1999; 44 (3): 400-6.

27 Stoicov C, Whary M, Rogers AB et al. Coinfection modulates inflammatory responses and clinical outcome of Helicobacter felis and Toxoplasma gondii infections. J Immunol 2004; 173 (5): 3329-36.

28 Bercik P, Verdu EF, Collins SM. Is irritable bowel syndrome a low-grade inflammatory bowel disease? Gastroenterol Clin North Am 2005; 34 (2): 235-45. 